\title{
Can Anthropization Govern the Variation in Water Table Levels, Water Flow and Carbon Losses? A Case Study in Tropical Mountain Peatlands an Serra Do Espinhaço Meridional, Minas Gerais, Brazil.
}

Uidemar Morais Barral ( $\nabla$ uidemarmorais@gmail.com )

Universidade de Brasilia https://orcid.org/0000-0002-6876-2883

Alexandre Christófaro Silva

UFVJM: Universidade Federal dos Vales do Jequitinhonha e Mucuri

Cristiano Christófaro

UFVJM: Universidade Federal dos Vales do Jequitinhonha e Mucuri

Camila Rodrigues Costa

UFVJM: Universidade Federal dos Vales do Jequitinhonha e Mucuri

Aparecido Penafort Filho

UFVJM: Universidade Federal dos Vales do Jequitinhonha e Mucuri

Geisla Mendes Macedo

UFVJM: Universidade Federal dos Vales do Jequitinhonha e Mucuri

Diêgo Faustolo Alves Bispo

UFVJM: Universidade Federal dos Vales do Jequitinhonha e Mucuri

Thamires Sabrina Gonçalves

UFVJM: Universidade Federal dos Vales do Jequitinhonha e Mucuri

Research Article

Keywords: wetlands, specific yield, water retention, environmental services, Histossols

Posted Date: January 5th, 2022

DOI: https://doi.org/10.21203/rs.3.rs-1074789/v1

License: (c) (i) This work is licensed under a Creative Commons Attribution 4.0 International License.

Read Full License 


\section{Abstract}

Peatlands are ecosystems formed by organic matter ( $\sim 15 \%$ of the total mass) and water $(\sim 85 \%$ of the total mass), and constitute a particular type of free aquifer. They perform important hydrological functions by storing excess water during rainfall events, contributing to the baseflow of its rivers throughout the year. Degradation affects the dynamics of the water table, which, in turn, can influence the decomposition of organic matter content and the release of carbon into its waters. Its water retention capacity may also be compromised and reduce the volume of water available downstream, especially in the dry season. The aim of this study was to evaluate the effects of anthropic interference on variations in groundwater, water storage, and carbon flow in two tropical mountain peatlands, located at the head of the Araçuaí River, in Serra do Espinhaço Meridional (SdEM), Minas Gerais, Brazil. Groundwater levels were installed in piezometers distributed on a peatland located in a protected area (Natural Park) (Protected TP) and in a peatland located outside the conservation unit (Anthropized - TA). Data were analyzed considering the daily rainfall recorded by an automatic weather station installed in the study area. From the data on precipitation and water table level variation, the specific yield (Sy) in the two peatlands was calculated. The observed flows and the mean monthly Sy on each piezometer were correlated and their significance was verified using the t test $(p<0.05)$. The relationship between the observed flow and the mean monthly values of Sy obtained for the piezometers were verified through multiple regression. The specific yield correlated significantly with flow in both peatlands $(p<0.05)$. Multiple linear regression showed a coefficient of determination $\left(R^{2}\right)$ of 0.92 in both peatlands, indicating a direct relationship between Sy and observed flow. The TP presented a $43 \%$ smaller variation in the water table, a $7 \%$ higher specific yield and a specific flow rate of $13 \%$ higher in relation to the TA. The peatland located in a protected area retains more water, with less variation in flow throughout the year, and has less carbon output in the water compared to the anthropized peatland. The results demonstrated that anthropization is causing degradation of the peatland, reducing its water holding capacity and accelerating its carbon losses. In the medium term, these effects may lead to a drastic reduction in flow in the upper course of the Araçuaí River.

\section{Introduction}

Peatlands are transition environments between terrestrial and aquatic ecosystems and play an important hydrological role when storing excess water during rainfall events, thus maintaining the baseflow along the year. They are formed by organic soils, but are also known as special types of free aquifers, as they can recharge via the surface after each rainfall event (Acreman \& Holden, 2013; McLaughlin \& Cohen, 2014; Kettridge et al., 2015; Bourgault et al., 2017).

The hydrological dynamic also governs the carbon dynamic in tropical peatlands (Millar et al., 2018). Water table variation controls the decomposition rate of vegetal material, and thus the quantity and quality of carbon released into the waters. High organic carbon losses from peatlands also impair their ability to retain water and consequently to maintain good downstream water flow in dry seasons (Mitsch \& Gosselink, 2015). The water table on the surface of tropical peatlands plays a key role in maintaining 
organic soils and vegetation cover (Schimelpfenig et al., 2014; Millar et al., 2017). The variations in water table levels, water flows, evapotranspiration, and water storage capacity are greater in the superficial layers in mountain peatlands. These layers are mainly composed of a small amount of decomposed organic matter, with a large amount of pores and high saturated hydraulic conductivity. These characteristics favor increases in water flow and evapotranspiration when the water table reaches the soil surface; the opposite occurring when there is a reduction in the water table level (White, 1932; Rosa \& Larocque, 2008; Bourgault et al., 2017).

Water retention is also higher in the upper layers compared to the deeper layers, due to its greater porosity. Campos et al. (2011), studying peatlands in the Serra do Espinhaço Meridional (SdEM), reported up to $17 \mathrm{~g}$ of water being retained in each gram of peat in upper layers. They also reported that the water retention capacity decreases with depth, where the organic matter is in a state of advanced decomposition.

The water from the recharge area runs down superficial and subsurface paths during rainfall events until it reaches the peatland. As a result, there is an increase in the levels of the water table and water stored in the upper soil layers. When the rainfall stops, losses due to evapotranspiration and the superficial flow of water stored in these layers begin. Therefore, the ratio between rainfall volume and water table level can provide an estimate of the water that can flow freely ("free water"), called here specific yield (Sy).

Reductions in Sy and water table level are closely related to human-induced activities (eg. burning and silting), which can considerably increase decomposition rates and hydrophobia of organic matter in soil layers. Responses to these activities are clearly detected in the water color. Peat waters are usually very dark after rainfall events, when the water table level rises and high amounts of carbon are released from the upper layers of the soil into the waters (Freeman et al., 1993; Surahman et al., 2018). Dissolved organic carbon in the water gives the darkest color waters in mountain peatlands.

Studies in the Amazon region demonstrate a direct relationship between total organic carbon (TOC) concentrations and river water levels (Sargentini Junior et al., 2001; Suhett et al., 2007; C. F. da Silva, 2013). Therefore, monitoring the Sy also makes it possible to assess the carbon flow in river waters.

The Serra do Espinhaço Meridional (SdEM) is home to the headwaters of three important basins in eastern Brazil, the São Francisco, Doce, and Jequitinhonha river basins. Most of the peatlands mapped in SdEM (over 14,000 ha) are headwaters and regulate the water flow of their rivers in the dry seasons (J. R. da R. Campos et al., 2012; M. L. da Silva et al., 2013). However, many of these peatlands suffer high anthropic pressure due to periodic fires, intensive grazing, erosion, and silting.

Several studies have reported the negative effects of anthropization on the capacity of peat bogs to store carbon and water (Thompson \& Waddington, 2013a, 2013b; Waddington et al., 2015; Bispo et al., 2016). Thus, in order to better understand the hydrological functions and carbon flows in peatlands, it is essential to have deeper knowledge based on field data. 
This study aimed to evaluate the effect of human-induced activities on water and carbon dynamics in tropical mountain peatlands from the headwaters of the Araçuaí River - MG. In the present study, we used an approach based on field data on variations in water table levels, water flow, water storage, and carbon flow collected over a two-year period.

\section{Materials And Methods}

\subsection{Site location}

The studied peatlands are located in the Chapadão do Couto, SdEM (Fig. 1). The protected peatland (TP) is encompassed by the Parque Estadual do Rio Preto (Rio Preto State Park) (PERP) and forms the headwater of the Rio Preto, a tributary of the Araçuaí River. The TP recharge area covers 36.59 ha of the PERP, with $9.81 \%$ of this area corresponding to the peatland itself.

The anthropized peatland (TA) is the main headwater of the Araçuaí River. It is outside the conservation unit and has been used for grazing cattle and horses. This peatland has been subjected to periodic burning, animal trampling, and erosion (Fig. 2). The TA recharge area is 101.29 ha, with $11.02 \%$ corresponding to the peatland itself.

The two peatlands are under the same climate regime, type Cwb (mesothermal) according to the Köppen classification, with well-defined rainy and dry seasons; the average temperature of the coldest 3 months is from 10 to $15^{\circ} \mathrm{C}$. Quartzitic lithology, where hematitic phyllites and phyllites appear in small proportions, serves as a framework for the studied peatlands. These Histossols are mainly in depressions, where there is a greater supply of organic matter due to water accumulation, anaerobiosis, and dystrophy, limiting the activity of soil microbiota (J. R. da R. Campos et al., 2010; M. L. da Silva et al., 2013). The drains of the studied peatlands go through different sub-basins that make up the Araçuaí River Basin (ARB), draining an area of about $16,280 \mathrm{~km}^{2}$, covering 23 municipalities in the northeast of the state of Minas Gerais, Brazil. Ten municipalities use the waters of the Araçuaí River for daily drinking water.

2.2. Monitoring of rainfall and water flow at the peat outlet

The rainfall data were monitored through a meteorological station (HOBO, model U30-NRC) installed in the PERP (23 k 0676967 S 7,983,491 W; 1,573 m altitude) on July 12, 2016. Data were recorded at hourly intervals. The pluviometer records up to $127 \mathrm{~mm}$ of rainfall per hour, with an accuracy of $\pm 1 \%$, and a resolution of $0.2 \mathrm{~mm}$.

The water flow velocity was recorded every two months at the peat outlet using a fluviometric micro-reel. Water flow was then calculated from the product of the flow velocity and the channel cross-sectional area, according to the ISO, 748 (2007) methodology.

2.3. Installation of piezometers and water table level measuring devices 
Piezometers (Pz.) were installed in the center, at the edge, and close to the peat channel. The installation depth has been defined so that the Pz. encompass any variation in water table levels. The Pz. were made with aluminum tubes ( $8 \mathrm{~cm}$ in diameter) punctured from the base to a height of $50 \mathrm{~cm}$ and covered with cloth. Its base and top were capped and its construction was adapted from Freitas and Schietti (2015). Water table level measuring devices (HOBO, model U20L-01), data loggertype, with a resolution of 0.21 $\mathrm{cm}$ were installed in the Pz.

Four Pz. with water table level measuring devices were installed in the TP on August 25, 2016, and three were installed in the TA on September 22, 2016. Water table level measuring devices were programmed to record the water table level variation data every 30 minutes, with data being collected from August 2016 to July 2018.

2.4. Daily variation in water table level $\left(\Delta \mathrm{h}_{\mathrm{d}}\right)$ and specific yield (Sy)

$\Delta \mathrm{h}_{\mathrm{d}}$ was calculated for each $\mathrm{Pz}$. by subtracting the value of the water table level measured on the previous day $\left(\mathrm{N}_{\mathrm{da}}\right.$, in $\left.\mathrm{mm}\right)$ from the level measured on the day $\left(\mathrm{N}_{\mathrm{d}}\right.$, in $\left.\mathrm{mm}\right)$ (Eq. (1)).:

$\Delta h_{d}=N_{d}-N_{d a}(1)$

The Sy calculation was adapted from Bourgault et al (2017). The amount of water recharging is the rainfall and the time of arrival of water in the peatland after a precipitation event is relatively short. Thus, the Sy was calculated using Eq. 2, taking into account the data on rainfall volume in each event $(P)$, in $\mathrm{mm}$, and the variation in the water table level $(\Delta \mathrm{h})$, in $\mathrm{mm}$, during the event in each $\mathrm{Pz}$. in the two peatlands:

$S y=P / \Delta h(2)$

The Sy estimate as a function of the water table level variation is more accurate when precipitation events are infrequent - and they can be easily isolated in the hydrographic record - and when the period of change between precipitation and recharge is short in compared response times for the horizontal flow of the groundwater. Thus, the method requires regular records of water table level variation. Furthermore, as the method is based on point estimates of Sy, its calculation must be repeated at several points, in order to obtain a more accurate estimate of global peat Sy (Fitts, 2013).

Global Sy was calculated through Eq. 3, using the data on rainfall volume $\left(\sum P\right)$, in $\mathrm{mm}$, and water table level $\left(\sum \Delta h\right)$, in $\mathrm{mm}$, obtained during consecutive precipitation events, as follows:

Sy $=\sum \mathrm{P} / \sum \Delta \mathrm{h}(3)$

Mean monthly Sy was calculated using the mean of the Sy values, for each precipitation event, which enabled its relation to other evaluated parameters, mainly the flow.

In wetlands such as peatlands, when Sy is chronologically interpreted, there is a better understanding of its behavior after each precipitation event. Sy between 0 and 1 is obtained when the water levels in the 
peat are below the surface. Sy values close to 1.0 mean a high rate of water accumulation from rainfall in porous spaces. Sy greater than 1.0 indicates accumulation of water above the surface of the soil, resulting from the additional entry of water through runoff, infiltration into the recharge area, or direct rainfall on the peatland (Loheide et al., 2005; Holden, 2009; McLaughlin \& Cohen, 2014).

\subsection{Water sampling and analysis of total organic carbon}

Three water sampling points (Fig. 1) were selected within each studied peatland according to the representativeness of the areas, ease of access to the sites, and apparent water flow. Sampling was carried out in a single period of the day, every two months, totaling 11 samples per sampling point. The first sample was taken in September 2016, at the end of the dry season, and the last was taken in July 2018, mid-dry season.

The water samples were transported to the laboratory for analysis in sterile polyethylene bottles (300 ml capacity) inside a thermal box containing ice. The samples were then analyzed according to a methodology adapted from APHA and AWWA (2005), whereby $2.5 \mathrm{ml}$ aliquots of the samples were digested in an acid medium with $\mathrm{K}_{2} \mathrm{Cr}_{2} \mathrm{O}_{2}$ titrated with $\mathrm{Fe}\left(\mathrm{NH}_{4}\right)_{2}\left(\mathrm{SO}_{4}\right)_{2}$ to obtain the TOC using Eq. 4:

TOC $=(B-A) \times C \times 3000 /$ sample volume $(4)$

Where,

$\mathrm{TOC}=$ total organic carbon $\left(\mathrm{mg} \mathrm{L}^{-1}\right)$;

$\mathrm{B}=\mathrm{mL}$ of $\mathrm{Fe}\left(\mathrm{NH}_{4}\right)_{2}\left(\mathrm{SO}_{4}\right)_{2}$ spent on the blank sample;

$\mathrm{A}=\mathrm{mL}$ of $\mathrm{Fe}\left(\mathrm{NH}_{4}\right)_{2}\left(\mathrm{SO}_{4}\right)_{2}$ spent on the sample;

$\mathrm{C}=$ concentration of $\mathrm{Fe}\left(\mathrm{NH}_{4}\right)_{2}\left(\mathrm{SO}_{4}\right)_{2}$;

$3,000=$ carbon equivalent-gram $\times 1,000 \mathrm{~mL} \mathrm{~L}^{-1}$.

\subsection{Data analysis}

The recorded outflow data were correlated with the average monthly Sy data recorded on each Pz and their significance was tested using the t test ( $p$-value $<0.05$ ). These data were also subjected to multiple linear regressions using the least squares method, in which the dependent variable was observed water flow and the independent variables were the mean monthly values of Sy obtained on each Pz. The significance of the equations was tested using the $F$ test $(p<0.05)$ and the significance of the regression coefficients using the $t$ test $(P<0.05)$.

The mean monthly Sy and COT values were interpolated through the inverse distance weighting (IDW) method using the QGIS 2.18.22 program. The absence of spatial structure limited the use of kriging in data interpolation. 


\section{Results And Discussion}

\subsection{Variation in water table level $(\Delta h)$}

The mean variation range of the $\Delta \mathrm{h}$ was $43 \%$ greater in the TA compared to the TP (Table 1 ).

In the TP, the data recorded on the piezometers decrease from the edges to the center of the peatland (Table 1). The greater range of $\Delta \mathrm{h}$ values in Pz. 4 is explained by the proximity of this $\mathrm{Pz}$ to the outlet (lowest level) and the channel, where the water flow is faster, since the channel receives the water drained from both the peatland and its recharge area. When precipitation ends, the channel becomes the main flow path for free water, which is not retained by organic matter, and therefore the level of the water table falls quickly.

In the TA, the data recorded on the piezometers decrease with increasing altitude (Table 1). The range of $\Delta \mathrm{h}$ values recorded on Pz. 3 is twice as high as those recorded on the other piezometers, which implies rapid loss of free water in this peatland.

Regarding response to precipitation events (Fig. $3 \mathrm{~A}$ ), $\Delta \mathrm{h}_{\mathrm{d}}$ was also influenced by the position of the Pz. In the TP, $\Delta \mathrm{h}_{\mathrm{d}}$ showed a lower frequency of oscillation on Pz.03 (Fig. 3D), since the water reaches the center mainly through the saturated zone, and the flow depends on the decrease in the water level in the channel. The highest frequency of $\Delta h_{d}$ oscillation at the peat edge (Pz. 01 and 02) is related to the entry of water, mainly through surface runoff from the recharge area, notably during and immediately after more intense precipitation events (Fig. 3B and 3C).

On Pz. 04, $\Delta \mathrm{h}_{\mathrm{d}}$ was basically controlled by the flow in the channel (Fig. 3E). Thus, it can be inferred that the edges of the peatland receive the largest volume of water from surface runoff. When an intense precipitation event stops, this water reaches the channel mainly through superficial flow and subsequently via subsurface flow. As the movement of water in the saturated zone is slow and influenced by the high retention power of organic matter (R. Campos et al., 2011), the water reaches the channel at an ever-lower speed after the end of a precipitation event. Thus, the specific flow in the exhaust decreases until it becomes constant, even in periods of drought (Fig. 10).

In the TA, $\Delta \mathrm{h}_{\mathrm{d}}$ had higher oscillation frequency on Pz. installed in the center (1 and 3) (Fig. 4B and 4D) and less oscillation frequency on Pz. 2, installed closest to the channel (Fig. 4C).

The low vegetation cover in the recharge area, which was caused by human-induced activities, caused a significant increase in runoff towards the TA. The higher density and impermeable and hydrophobic characteristics in the upper layer of the soil were caused by frequent fires, and drastically reduced the capacity of the TA to retain water (DeBano, 2000; Dekker et al., 2000; Thompson et al., 2014; Bispo et al., 2016).

3.2. Specific yield (Sy) 
The mean monthly Sy values ranged from 0.06 to 2.60 in the TA and from 0.06 to 2.15 in the TP. The outliers were observed on Pz. 1, 2 and 4 of the TP, and on the 3 piezometers in TA (Fig. 5).

There was a direct relationship between the mean monthly Sy values and precipitation (Fig. 7). In most of the studied period, the water was close to the surface of the peatlands, with Sy values between 0.50 and 1.17. This can be confirmed by the positive asymmetry of the mean monthly Sy data from Pz. 1, 2 and 3 in the TP and Pz. 1 and 2 in the TA (Fig. 5).

In both peatlands, the lowest mean values of Sy were observed on upstream Pz. (Pz. 1 and 2), indicating a decrease in the water level on the surface and its movement towards Pz. closer to the outlet (Table 2).

Several factors can contribute to the lower Sy values observed in the TA, specifically on Pz. 3 (Table 2). One such factor is the lower water retention capacity in the upper soil layers (hydrophobia), which drastically reduces the rise of water through capillarity, resulting in lowering of the water table level and in Sy close to zero, which indicates the presence of water in the basal layers, but not in the upper layers.

The water flow from the upper slopes in the TP is slower and the water table level remains close to that of the upper layer at the outlet. As a result, there is less variation in water flow and production over the year. The water retention capacity on the surface was lower in the TA due to fires, silting, and animal trampling. As a result, water in the TA moves faster with more varied flow, and water production becomes irregular over the year.

The daily Sy values reached 13.5 in the TP and 7.5 in the TA (Fig. 6) and they were also higher than those reported for temperate peatlands, which vary between 0 and 1.1 (McLaughlin \& Cohen, 2014; Moore et al., 2015; Dettmann \& Bechtold, 2016; Bourgault et al., 2017). This difference may have been due to the rainfall volume of each event. In temperate regions, rainfall is sparse and its daily volume is usually lower than that observed for tropical regions (McLaughlin \& Cohen, 2014; Moore et al., 2015; Dettmann \& Bechtold, 2016; Bourgault et al., 2017). The methodology used was also adapted to consider all rain events, not just the isolated events (Bourgault et al., 2017), and those that caused the sheet to rise less than $10 \mathrm{~mm}$ were disregarded. With the consecutive events, the Sy values were high, higher than 1.0, due to the large volume of water transported to the peatland areas.

Periodic fires in the TA increase surface runoff of soil particles from the recharge area to the channels, which besides silting the peatland, decrease soil porosity and increase bulk soil density. In addition, waterproofing of soil layers occurs when the peatland edges are burned. Water-repellent soil layers have also been found in upper layers of post-fire organic soils in Alaska (O'Donnell et al., 2009; Beatty \& Smith, 2013).

3.3. Relationship between specific yield (Sy) and waterflow

There was a positive correlation $(p<0.05)$ between Sy and the flow observed on all Pz. in the two peatlands (Table 3 ). In the TP peatland, the highest correlation coefficient (r) was observed on Pz. 4, close to the outlet. 
The combined contribution of the monthly mean values of Sy on the outflow was analyzed using multiple linear regression. In both peatlands, the equations obtained were significant $\left(p<0.05, R^{2}=0.92\right)($ Table 4$)$.

In the TP, the observed flow $(p=0.006)$ had a significant contribution from only the mean monthly values of Sy recorded on Pz. 4 (Table 4). The lower values of Sy on Pz. 4 (rainy season) compared to those recorded on the other Pz. indicated superficial flow towards the outlet. The inverse behavior observed in the dry season indicated a greater contribution of groundwater to the outflow (Fig. 7B).

In the TP, the observed flow $(p=0.006)$ had a significant contribution from the mean monthly values of Sy recorded on Pz. 2 and $3(p=0.04$ and $p=0.02$, respectively - Table 4). In the rainy season, the hydrological dynamics in the TP behaved similarly to those of the TA. However, the mean monthly values of Sy for all piezometers are close in the dry season, indicating low outflow, reflecting their lower water storage capacity (Fig. 7C).

3.4. Spatialization of specific yield (Sy) and total organic carbon (TOC)

The estimated Sy values were higher in the center of the peatlands regardless of the collection season (Fig. 8 and 9). Furthermore, the highest amounts of TOC were obtained at the highest points of the TP (dry season) and the lowest of the TA (rainy season).

Sy values observed for the dry season were higher in the TP compared to the TA. These results enable the inference that the higher resilience of water in upper layers in the TP reduces the decomposition rate of organic matter in this peatland. In the dry season, the greatest reduction in the water table in the higher areas of the TP (Table 1) and the lowest flow were directly related to the highest TOC levels in the waters in these high areas (Fig. 8). Less carbon was released into the water because of the increase in the water table level in the rainy season. A strong synergy between organic matter and water retention is observed in the TP; the temporal maintenance of water in its upper layers reduces the decomposition rate of organic matter in the upper layers (decreasing the TOC in the water) and vice versa.

The values of Sy obtained for the two seasons studied were lower in the TA compared to those observed in the TP. These results demonstrate that the upper layers of the TA had their water retention capacity compromised by human-induced activities, which favored the increase in the decomposition rate of organic matter and TOC in their waters. In the rainy season, the TOC accumulates near the outlet, where the water flow is faster (Fig. 9).

\subsection{Waterflow and water storage}

Specific flow rates were calculated from the equations displayed in Table 4. The estimated flow rate was higher in the TA compared to the TP for most months (Fig. 1). However, the specific flow calculated for the TP was higher than that of the TA (Fig. 10), especially in the dry season.

According to (Tucci, 2007) and (Mitsch \& Gosselink, 2015), inundated areas have ambiguous behavior, being both water producers and transporters. This can be applied to peatlands, being water producers when the level of the rivers is low (dry season) and water carriers when the rivers are full (rainy season) 
and the peatlands are saturated. In the rainy season the water supplies the peat bogs and its rivers mainly through surface and underground runoff. In the dry season, the water that infiltrated the recharge area during the rainy season supplies the peatlands and their rivers (Fig. 10).

The TA showed higher peaks of observed flow, while the TP showed less oscillation of specific waterflow, especially in the dry season (Fig. 10). We can infer from these results that human-induced activities increased the runoff in the water recharge area and decreased the water storage capacity of the peatland. 3.5. Carbon flow

The TOC values found in the waters of the TP and the TA varied between 1.0 and $12.3 \mathrm{mg} \mathrm{C} \mathrm{L}^{-1}$ and between 1.0 and $8.9 \mathrm{mg} \mathrm{C} \mathrm{L}^{-1}$ respectively (Table 5).

The mean TOC values were higher upstream in the TP (P1 and P2) and downstream in the TA (P3) (Table 4). Mean TOC concentrations in peatland waters are among the typical values found in rivers from temperate regions ( $\left.3 \mathrm{mg} \mathrm{L}^{-1}\right)$ and humid tropical regions $\left(6 \mathrm{mg} \mathrm{L}^{-1}\right)$ (Meybeck, 1982; Dettmann \& Bechtold, 2016). However, concentrations higher than that of the peat waters studied here have been reported in the waters of the Rio Negro, in the Brazilian Amazon region (12 $\mathrm{mg} \mathrm{L}^{-1}$ ) (Meybeck, 1982; Sargentini Junior et al., 2001; Suhett et al., 2007). Table 6 shows the $C$ output values recorded at the peatland outlet.

The volume of peat water plays an important role in carbon dynamics (Millar et al., 2018). There is gradual decomposition of the upper layers of the soil when the water table level decreases, leading to the formation of soluble organic acids (Blodau \& Moore, 2003; Laiho, 2006). As the water table level rises, due to the rise of water in the water recharge area, these acids are transported via surface flow to the outlet, coloring the waters, especially in the TA peatland (Fig. 8 and Fig. 9).

The two peatlands had higher TOC in their waters in the rainy season. The flow of TOC from the peatlands went towards the outlet because the water from the rise in the water table solubilizes the organic acids from the more accelerated decomposition of the upper layers of peat in the drier period.

The TOC flow of the TP was lower than that obtained for the TA, due mainly to the higher values of Sy in the dry season, which decreases the decomposition rates of upper layers. Thus, the TOC contents are lower, even with the rise of water table levels in the rainy season. The human-induced activities accelerated the decomposition of the upper TP layers, increasing the TOC content in the waters, which were higher than that observed for the TP (Table 6).

The TA and the TP show different behavior in relation to the $C$ output values recorded at the peatland outlet. Considering the accumulation rates of C observed by Bispo et al. (2016), there is a positive and negative net balance of $\mathrm{C}$ in the TP and the TA, respectively (Table 7).

The data showed that human-induced activities contributed greatly to the decomposition of organic matter and release of $\mathrm{C}$ into the water, as shown by the smaller amount of $\mathrm{C}$ stored in the anthropized 
peatland (Tab. 7). Similar results were found for tropical peatlands in Indonesia, in which the TOC flow was about $50 \%$ higher in anthropized peat waters than those in protected or native areas. Among the factors that contributed to the increase of $C$ in the waters, drainage, deforestation, and burning stood out, as they caused the lowering of the water table level and an increase in oxidation of the organic matter. Furthermore, there was also an increase in greenhouse gas losses and the amount of TOC in river waters (Moore et al., 2013; Miettinen et al., 2017).

\section{Conclusions}

Water and carbon dynamics from tropical mountain peatlands are quite sensitive to human-induced activities.

Protected peatlands produce more water, lose less carbon and have more constant outflow during the year compared with anthropized peatlands.

Preserving peatlands helps fix carbon in the soil and maintain the flow of its rivers.

\section{Declarations}

\section{Acknowledgements}

This work was supported by the National Council for Scientific and Technological Development - CNPq [Proc. 303666/2018-8 and 408162/2018-0]; the "Fundação de Amparo à Pesquisa do Estado de Minas Gerais" - FAPEMIG [Proc. CAG - APQ-01614-14 and PPM 00568-16); the "Coordenação de Aperfeiçoamento de Pessoal de Nível Superior" - (CAPES) [Financial Code 001]; and the "Coordenação de Aperfeiçoamento de Pessoal de Nível Superior" - CAPES [PNPD 2606/2011, Proc. 2338007759 / 201152]. We are also grateful to the Universidade Federal dos Vales do Jequitinhonha e Mucuri; and the Parque Estadual do Rio Preto.

\section{Conflict of interest}

The authors declare that they have no confict of interest.

\section{Availability of data and material}

Data available on request from the authors.

\section{Funding Sources}

This work was supported by the National Council for Scientific and Technological Development - CNPq [Proc. 303666/2018-8 and 408162/2018-0]; the "Fundação de Amparo à Pesquisa do Estado de Minas Gerais" - FAPEMIG [Proc. CAG - APQ-01614-14 and PPM 00568-16); the "Coordenação de Aperfeiçoamento de Pessoal de Nível Superior" - (CAPES) [Financial Code 001]; and the "Coordenação de 
Aperfeiçoamento de Pessoal de Nível Superior" - CAPES [PNPD 2606/2011, Proc. 2338007759 / 201152].

\section{References}

Acreman, M., \& Holden, J. (2013). How Wetlands Affect Floods. Wetlands, 33(5), 773-786. https://doi.org/10.1007/s13157-013-0473-2

Beatty, S. M., \& Smith, J. E. (2013). Dynamic soil water repellency and infiltration in post-wildfire soils. Geoderma, 192, 160-172. https://doi.org/10.1016/j.geoderma.2012.08.012

Bispo, D. F. A., Silva, A. C., Christofaro, C., Silva, M. L. N., Barbosa, M. S., Silva, B. P. C., Barral, U. M., \& Fabris, J. D. (2016). Hydrology and carbon dynamics of tropical peatlands from Southeast Brazil. CATENA, 143, 18-25. https://doi.org/10.1016/j.catena.2016.03.040

Blodau, C., \& Moore, T. R. (2003). Experimental response of peatland carbon dynamics to a water table fluctuation. Aquatic Sciences, 65(1), 47-62. https://doi.org/10.1007/s000270300004

Bourgault, M.-A., Larocque, M., \& Garneau, M. (2017). Quantification of peatland water storage capacity using the water table fluctuation method. Hydrological Processes, 31(5), 1184-1195.

https://doi.org/10.1002/hyp.11116

Campos, J. R. da R., Silva, A. C., Vasconcellos, L. L., Silva, D. V., Romão, R. V., Silva, E. de B., \& Grazziotti, P. H. (2010). Pedochronology and development of peat bog in the environmental protection area pau-defruta-Diamantina, Brazil. Revista Brasileira de Ciência do Solo, 34(6), 1965-1975.

https://doi.org/10.1590/S0100-06832010000600021

Campos, J. R. da R., Silva, A. C., \& Vidal-Torrado, P. (2012). Mapping, organic matter mass and water volume of a peatland in Serra do Espinhaço Meridional. Revista Brasileira de Ciência do Solo, 36(3), 723732. https://doi.org/10.1590/S0100-06832012000300004

Campos, R., Da, J. R., Silva, A. C., Fernandes, J. S. C., Ferreira, M. M., \& Silva, D. V. (2011). Water retention in a peatland with organic matter in different decomposition stages. Revista Brasileira de Ciência do Solo, 35(4), 1217-1227. https://doi.org/10.1590/S0100-06832011000400015

DeBano, L. F. (2000). The role of fire and soil heating on water repellency in wildland environments: A review. Journal of Hydrology, 231-232, 195-206. https://doi.org/10.1016/S0022-1694(00)00194-3

Dekker, L. W., Ritsema, C. J., \& Oostindie, K. (2000). Extent and significance of water repellency in dunes along the Dutch coast. Journal of Hydrology, 231-232, 112-125. https://doi.org/10.1016/S00221694(00)00188-8

Dettmann, U., \& Bechtold, M. (2016). Deriving Effective Soil Water Retention Characteristicsfrom Shallow Water Table Fluctuations in Peatlands. Vadose Zone Journal, 15(10), 0. 
Fitts, C. R. (2013). 6-Deformation, Storage, and General Flow Equations. In C. R. Fitts (Org.), Groundwater Science (Second Edition) (p. 187-242). Academic Press. https://doi.org/10.1016/B978-0-12-3847058.00006-6

Freeman, C., Lock, M. A., \& Reynolds, B. (1993). Impacts of Climatic Change On Peatland Hydrochemistry; A Laboratory-Based Experiment. Chemistry and Ecology, 8(1), 49-59.

https://doi.org/10.1080/02757549308035300

Holden, J. (2009). Flow through macropores of different size classes in blanket peat. Journal of Hydrology, 364, 342-348.

Kettridge, N., Turetsky, M. R., Sherwood, J. H., Thompson, D. K., Miller, C. A., Benscoter, B. W., Flannigan, M. D., Wotton, B. M., \& Waddington, J. M. (2015). Moderate drop in water table increases peatland vulnerability to post-fire regime shift. Scientific Reports, 5, 8063. https://doi.org/10.1038/srep08063

Laiho, R. (2006). Decomposition in peatlands: Reconciling seemingly contrasting results on the impacts of lowered water levels. Soil Biology and Biochemistry, 38(8), 2011-2024.

https://doi.org/10.1016/j.soilbio.2006.02.017

Loheide, S. P., Butler, J. J., \& Gorelick, S. M. (2005). Estimation of groundwater consumption by phreatophytes using diurnal water table fluctuations: A saturated-unsaturated flow assessment. Water Resources Research, 41(7). https://doi.org/10.1029/2005WR003942

McLaughlin, D. L., \& Cohen, M. J. (2014). Ecosystem specific yield for estimating evapotranspiration and groundwater exchange from diel surface water variation. Hydrological Processes, 28(3), 1495-1506. https://doi.org/10.1002/hyp.9672

Meybeck, M. (1982). Carbon, nitrogen, and phosphorus transport by world rivers. American Journal of Science, 282(4), 401-450. https://doi.org/10.2475/ajs.282.4.401

Miettinen, J., Hooijer, A., Vernimmen, R., Liew, S. C., \& Page, S. E. (2017). From carbon sink to carbon source: Extensive peat oxidation in insular Southeast Asia since 1990. Environmental Research Letters, 12(2), 024014. https://doi.org/10.1088/1748-9326/aa5b6f

Millar, D. J., Cooper, D. J., Dwire, K. A., Hubbard, R. M., \& von Fischer, J. (2017). Mountain Peatlands Range from CO2 Sinks at High Elevations to Sources at Low Elevations: Implications for a Changing Climate. Ecosystems, 20(2), 416-432. https://doi.org/10.1007/s10021-016-0034-7

Millar, D. J., Cooper, D. J., \& Ronayne, M. J. (2018). Groundwater dynamics in mountain peatlands with contrasting climate, vegetation, and hydrogeological setting. Journal of Hydrology, 561, 908-917. https://doi.org/10.1016/j.jhydrol.2018.04.050 
Mitsch, W. J., \& Gosselink, J. G. (2015). Wetlands. John Wiley \& Sons.

Moore, P. A., Morris, P. J., \& Waddington, J. M. (2015). Multi-decadal water table manipulation alters peatland hydraulic structure and moisture retention. Hydrological Processes, 29(13), 2970-2982. https://doi.org/10.1002/hyp.10416

Moore, P. A., Pypker, T. G., \& Waddington, J. M. (2013). Effect of long-term water table manipulation on peatland evapotranspiration. Agricultural and Forest Meteorology, 178-179, 106-119.

https://doi.org/10.1016/j.agrformet.2013.04.013

O’Donnell, J. A., Turetsky, M. R., Harden, J. W., Manies, K. L., Pruett, L. E., Shetler, G., \& Neff, J. C. (2009). Interactive effects of fire, soil climate, and moss on $\mathrm{CO} 2$ fluxes in black spruce ecosystems of interior Alaska. Ecosystems, 12(1), 16. https://doi.org/10.1007/s10021-008-9206-4

Rosa, E., \& Larocque, M. (2008). Investigating peat hydrological properties using field and laboratory methods: Application to the Lanoraie peatland complex (southern Quebec, Canada). Hydrological Processes, 22(12), 1866-1875. https://doi.org/10.1002/hyp.6771

Sargentini Junior, É., Rocha, J. C., Rosa, A. H., Zara, L. F., \& Santos, A. dos. (2001). Substâncias húmicas aquáticas: Fracionamento molecular e caracterização de rearranjos internos após complexação com íons metálicos. Química Nova, 24(3), 339-344. https://doi.org/10.1590/S0100-40422001000300010

Schimelpfenig, D. W., Cooper, D. J., \& Chimner, R. A. (2014). Effectiveness of Ditch Blockage for Restoring Hydrologic and Soil Processes in Mountain Peatlands. Restoration Ecology, 22(2), 257-265.

https://doi.org/10.1111/rec.12053

Silva, C. F. da. (2013). Relação entre carbono orgânico dissolvido (COD) e elementos metálicos em águas naturais da porção leste do Quadrilátero Ferrífero-MG.

http://www.repositorio.ufop.br/handle/123456789/3286

Silva, M. L. da, Silva, A. C., Silva, B. P. C., Barral, U. M., Soares, P. G. e S., \& Vidal-Torrado, P. (2013). Surface mapping, organic matter and water stocks in peatlands of the Serra do Espinhaço meridional-Brazil. Revista Brasileira de Ciência do Solo, 37(5), 1149-1157. https://doi.org/10.1590/S010006832013000500004

Suhett, A. L., Amado, A. M., Enrich-Prast, A., Esteves, F. de A., \& Farjalla, V. F. (2007). Seasonal changes of dissolved organic carbon photo-oxidation rates in a tropical humic lagoon: The role of rainfall as a major regulator. Canadian Journal of Fisheries and Aquatic Sciences, 64(9), 1266-1272.

https://doi.org/10.1139/f07-103

Surahman, A., Soni, P., \& Shivakoti, G. P. (2018). Are peatland farming systems sustainable? Case study on assessing existing farming systems in the peatland of Central Kalimantan, Indonesia. Journal of Integrative Environmental Sciences, 15(1), 1-19. https://doi.org/10.1080/1943815X.2017.1412326 
Thompson, D. K., Benscoter, B. W., \& Waddington, J. M. (2014). Water balance of a burned and unburned forested boreal peatland. Hydrological Processes, 28(24), 5954-5964.

https://doi.org/10.1002/hyp.10074

Thompson, D. K., \& Waddington, J. M. (2013a). Wildfire effects on vadose zone hydrology in forested boreal peatland microforms. Journal of Hydrology, 486, 48-56.

https://doi.org/10.1016/j.jhydrol.2013.01.014

Thompson, D. K., \& Waddington, J. M. (2013b). Wildfire effects on vadose zone hydrology in forested boreal peatland microforms. Journal of Hydrology, 486, 48-56.

https://doi.org/10.1016/j.jhydrol.2013.01.014

Tucci, C. E. M. (2007). Hidrologia: Ciência e aplicação. Editora da UFRGS.

Waddington, J. M., Morris, P. J., Kettridge, N., Granath, G., Thompson, D. K., \& Moore, P. A. (2015).

Hydrological feedbacks in northern peatlands. Ecohydrology, 8(1), 113-127.

https://doi.org/10.1002/eco.1493

White, W. N. (1932). A method of estimating ground-water supplies based on discharge by plants and evaporation from soil: Results of investigations in Escalante Valley, Utah (USGS Numbered Series No 659A; Water Supply Paper, p. 115). U.S. Government Printing Office.

http://pubs.er.usgs.gov/publication/wsp659A

\section{Tables}

Table 1 Information on the locations where the piezometers (Pz.) were placed and on the variables recorded in them. 


\begin{tabular}{|c|c|c|c|c|c|c|c|c|}
\hline Peatland & Pz. & $\begin{array}{l}\text { Pz. } \\
\text { depth }\end{array}$ & $\begin{array}{l}\text { Site } \\
\text { depth }\end{array}$ & Altitude & $\begin{array}{l}\text { Maximum } \\
\text { variation* }\end{array}$ & $\begin{array}{l}\text { Minimum } \\
\text { variation* }\end{array}$ & Range & $\begin{array}{l}\text { Peat } \\
\text { position }\end{array}$ \\
\hline & & - & 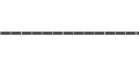 & m- - & -_-_- & & & \\
\hline \multirow[t]{4}{*}{ TA } & 1 & 1.31 & 3.99 & 1,601 & 0.173 & -0.058 & 0.23 & Edge \\
\hline & 2 & 1.65 & 1.88 & 1,598 & 0.127 & -0.051 & 0.18 & Edge \\
\hline & 3 & 1.27 & 1.40 & 1,594 & 0.102 & -0.040 & 0.14 & Center \\
\hline & 4 & 0.63 & 1.47 & 1,589 & 0.165 & -0.121 & 0.29 & Chanel \\
\hline Mean & & & & & & & 0.21 & \\
\hline \multirow[t]{4}{*}{ TP } & 1 & 1.84 & 3.48 & 1,586 & 0.157 & -0.067 & 0.22 & Center \\
\hline & 2 & 1.28 & 1.74 & 1,584 & 0.191 & -0.041 & 0.23 & Center / \\
\hline & & & & & & & & Chanel \\
\hline & 3 & 1.13 & 2.11 & 1,582 & 0.350 & -0.086 & 0.44 & Center \\
\hline Mean & & & & & & & 0.30 & \\
\hline
\end{tabular}

*Regarding the reference (water table level $=0$ ) recorded on the first day in both protected $(T P)$ and anthropized (TA) peatlands.

Table 2 Average values of specific yield (Sy) for piezometers (Pz.) in protected (TP) and anthropized (TA) peatlands. 
Month TP

TA
Pz. 01
Pz. 02
Pz. 03 Pz. 04
Pz. 01 Pz. 02
Pz. 03

\begin{tabular}{|c|c|c|c|c|c|c|c|}
\hline 16/Sep. & 0.12 & 0.11 & 0.23 & 0.28 & 0.23 & 0.38 & 0.26 \\
\hline 16/Oct. & 0.35 & 0.34 & 2.59 & 1.10 & 1.05 & 0.19 & 0.12 \\
\hline 16/Nov. & 0.69 & 0.53 & 1.67 & 0.92 & 0.52 & 0.60 & 0.46 \\
\hline 16/Dec. & 1.91 & 2.95 & 2.15 & 2.32 & 1.96 & 1.89 & 0.99 \\
\hline 17/Jan. & 0.53 & 0.20 & 0.95 & 0.75 & 0.22 & 0.51 & 0.35 \\
\hline 17/Feb. & 1.12 & 0.64 & 1.86 & 0.76 & 0.55 & 0.60 & 0.48 \\
\hline 17/Mar. & 0.68 & 0.32 & 0.92 & 0.55 & 1.06 & 0.56 & 0.45 \\
\hline 17/Apr. & 0.28 & 0.16 & 0.59 & 0.37 & 0.16 & 0.26 & 0.14 \\
\hline 17/May & 0.48 & 1.71 & 0.68 & 0.40 & 0.25 & 0.46 & 0.25 \\
\hline 17/Jun. & 0.34 & 0.16 & 1.10 & 0.88 & 0.16 & 0.55 & 0.19 \\
\hline 17/Jul. & 0.41 & 0.24 & 0.91 & 0.57 & 0.39 & 0.42 & 0.18 \\
\hline 17/Aug. & 0.11 & 0.06 & 0.26 & 0.37 & 0.06 & 0.06 & 0.08 \\
\hline 17Sep. & 0.13 & 0.09 & 0.33 & 0.51 & 0.10 & 0.20 & 0.11 \\
\hline 17/Oct. & 0.11 & 0.09 & 0.27 & 0.44 & 0.09 & 0.15 & 0.12 \\
\hline 17/Nov. & 0.43 & 0.60 & 0.93 & 0.58 & 0.36 & 0.74 & 0.35 \\
\hline 17/Dec. & 1.37 & 1.24 & 1.49 & 0.53 & 0.92 & 2.66 & 0.64 \\
\hline 18/Jan. & 0.69 & 0.69 & 1.26 & 0.51 & 0.38 & 1.15 & 0.38 \\
\hline 18/Feb. & 1.87 & 1.91 & 2.00 & 0.67 & 0.90 & 1.69 & 0.65 \\
\hline 18/Mar. & 1.73 & 1.63 & 1.79 & 0.73 & 0.96 & 1.84 & 0.93 \\
\hline 18/Apr. & 1.32 & 1.76 & 1.82 & 0.73 & 1.57 & 2.60 & 1.56 \\
\hline 18/May & 0.28 & 0.43 & 0.35 & 0.38 & 0.49 & 0.58 & 0.44 \\
\hline 18/Jun. & 0.25 & 0.23 & 0.33 & 0.24 & 0.63 & 1.42 & 0.93 \\
\hline 18/Jul. & 0.33 & 0.23 & 0.52 & 0.51 & 0.37 & 1.16 & 0.42 \\
\hline Mean & 0.68 & 0.71 & 1.09 & 0.66 & 0.58 & 0.90 & 0.46 \\
\hline
\end{tabular}

Table 3 Pearson's correlation coefficient ( $r$ ) between the monthly mean values of Sy recorded in piezometers (Pz.) and the outflow of the studied peatlands. 


\begin{tabular}{|c|c|c|c|c|c|c|}
\hline \multicolumn{4}{|c|}{ Protected peatland } & \multicolumn{3}{|c|}{ Anthropized peatland } \\
\hline Pz.01 & Pz.02 & Pz.03 & Pz.04 & Pz.01 & Pz.02 & Pz.03 \\
\hline $0.75^{\star}$ & $0.71^{*}$ & $0.67^{\star}$ & $0.94 *$ & $0.90 *$ & $0.71^{*}$ & $0.89 *$ \\
\hline
\end{tabular}

*significant $(p<0.05)$ by the t test.

Table 4 Multiple linear models for the monthly mean values of Sy recorded in piezometers (Pz.) and the outflow of the studied peatlands.

\begin{tabular}{|lll|}
\hline Peatland & Model & $R^{2}$ \\
\hline Anthropized & $0.001+0.005$ Sy $1-0.002$ Sy $2-0.003$ Sy3 $+0.008 *$ Sy 4 & $0.92 *$ \\
\hline Preserved & $0.002+0.007$ Sy $1-0.009 *$ Sy $2+0.031 *$ Sy3 & $0.92 *$ \\
\hline
\end{tabular}

Table 5 Total organic carbon (TOC) content in water recorded at the sampling points (P) in studied peatlands.

\begin{tabular}{|c|c|c|c|c|c|c|}
\hline \multirow[t]{3}{*}{ Sampling date } & \multicolumn{6}{|c|}{ Peatland } \\
\hline & \multicolumn{3}{|c|}{ Protected } & \multicolumn{3}{|c|}{ Anthropized } \\
\hline & $\mathrm{P} 1$ & P2 & P3 & $\mathrm{P} 1$ & $\mathrm{P} 2$ & P3 \\
\hline & \multicolumn{6}{|c|}{$\mathrm{TOC}\left(\mathrm{mg} \mathrm{L}^{-1}\right)$} \\
\hline $2016 / 09 / 22$ & 2.8 & 3.1 & 2.9 & 7.8 & 2.7 & 1.7 \\
\hline 2016/12/15 & 1.0 & 1.3 & 1.8 & 1.0 & 3.8 & 5.8 \\
\hline $2017 / 02 / 16$ & 5.7 & 3.2 & 3.1 & 3.2 & 4.5 & 6.0 \\
\hline $2017 / 05 / 16$ & 12.3 & 4.6 & 2.0 & 4.4 & 4.5 & 3.5 \\
\hline $2017 / 07 / 20$ & 9.4 & 3.2 & 3.5 & 2.8 & 5.6 & 5.0 \\
\hline $2017 / 09 / 20$ & 2.9 & 4.0 & 1.7 & 2.3 & 3.7 & 2.9 \\
\hline $2017 / 11 / 16$ & 7.1 & 5.9 & 5.0 & 4.8 & 8.9 & 8.2 \\
\hline $2018 / 01 / 26$ & 1.9 & 2.5 & 1.7 & 5.0 & 7.4 & 7.6 \\
\hline $2018 / 03 / 27$ & 4.8 & 9.3 & 5.7 & 6.4 & 5.1 & 7.2 \\
\hline 2018/05/17 & 5.8 & 4.6 & 2.6 & 6.9 & 4.0 & 4.3 \\
\hline $2018 / 07 / 24$ & 2.9 & 3.8 & 3.8 & 3.3 & 2.9 & 3.1 \\
\hline Mean & 5.2 & 4.1 & 3.1 & 4.4 & 4.8 & 5.0 \\
\hline
\end{tabular}


Table 6 C output values recorded at the peatland outlet.

Sampling date Peatland

\begin{tabular}{lllll} 
& Protected & & \multicolumn{2}{l}{ Anthropized } \\
\cline { 2 - 5 } & Cload $\left(\mathrm{mg} \mathrm{s}^{-1}\right)$ & $\begin{array}{l}\text { C output } \\
\left(\text { t year }^{-1}\right)\end{array}$ & $\begin{array}{l}\text { C load } \\
\left(\mathrm{mg} \mathrm{s}^{-1}\right)\end{array}$ & $\begin{array}{l}\text { C output } \\
\left(\mathrm{t} \mathrm{year}^{-1}\right)\end{array}$ \\
\hline $2016 / 09 / 22$ & 11.47 & 0.36 & 9.66 & 0.30 \\
\hline $2016 / 12 / 15$ & 31.89 & 1.01 & 168.33 & 5.31 \\
\hline $2017 / 02 / 16$ & 25.13 & 0.79 & 85.08 & 2.68 \\
\hline $2017 / 05 / 16$ & 5.81 & 0.18 & 18.54 & 0.58 \\
\hline $2017 / 07 / 20$ & 11.50 & 0.36 & 21.92 & 0.69 \\
\hline $2017 / 09 / 20$ & 10.70 & 0.34 & 24.97 & 0.79 \\
\hline $2017 / 11 / 16$ & 11.01 & 0.35 & 60.21 & 1.90 \\
\hline $2018 / 01 / 26$ & 3.95 & 0.12 & 19.40 & 0.61 \\
\hline $2018 / 03 / 27$ & 35.77 & 1.13 & 143.69 & 4.53 \\
\hline $2018 / 05 / 17$ & 7.67 & 0.24 & 60.50 & 1.91 \\
\hline $2018 / 07 / 24$ & 16.73 & 0.53 & 29.51 & 0.93 \\
\hline Mean & $\mathbf{1 5 . 6 0}$ & $\mathbf{0 . 4 9}$ & $\mathbf{5 8 . 3 5}$ & $\mathbf{1 . 8 3}$
\end{tabular}

Table 7 Carbon balance in tropical mountain peatlands.

\begin{tabular}{|c|c|c|c|c|c|c|c|}
\hline \multirow[t]{3}{*}{ Peatland } & \multicolumn{2}{|c|}{$\begin{array}{l}\text { Semidecidual } \\
\text { Seasonal Forest }\end{array}$} & \multicolumn{5}{|l|}{$\begin{array}{l}\text { Wet } \\
\text { Field }\end{array}$} \\
\hline & Area & Input soil C* & Area & $\begin{array}{l}\text { Input } \\
\text { soil C* }\end{array}$ & $\begin{array}{l}\text { Total soil C } \\
\text { input (A) }\end{array}$ & $\begin{array}{l}\text { C output } \\
\text { (M) }\end{array}$ & $\begin{array}{l}A- \\
M\end{array}$ \\
\hline & -ha- & $\mathrm{g} \mathrm{m}^{-2}$ year $^{-1}$ & -ha- & $\begin{array}{l}\mathrm{g} \mathrm{m}^{-2} \\
\text { year }^{-1}\end{array}$ & $\ldots$ & - & \\
\hline Protected & 0.26 & 13.37 & 3.33 & 29.68 & 0.52 & 0.49 & 0.03 \\
\hline Anthropized & 0.64 & 8.52 & 9.74 & 15.35 & 0.92 & 1.83 & -0.91 \\
\hline
\end{tabular}

*Bispo et al. (2016); M: recorded at the peatland outlet.

Figures 


\section{Figure 1}

Legend not included with this version

\section{Figure 2}

Legend not included with this version

\section{Figure 3}

Legend not included with this version

\section{Figure 4}

Legend not included with this version

\section{Figure 5}

Legend not included with this version

\section{Figure 6}

Legend not included with this version 

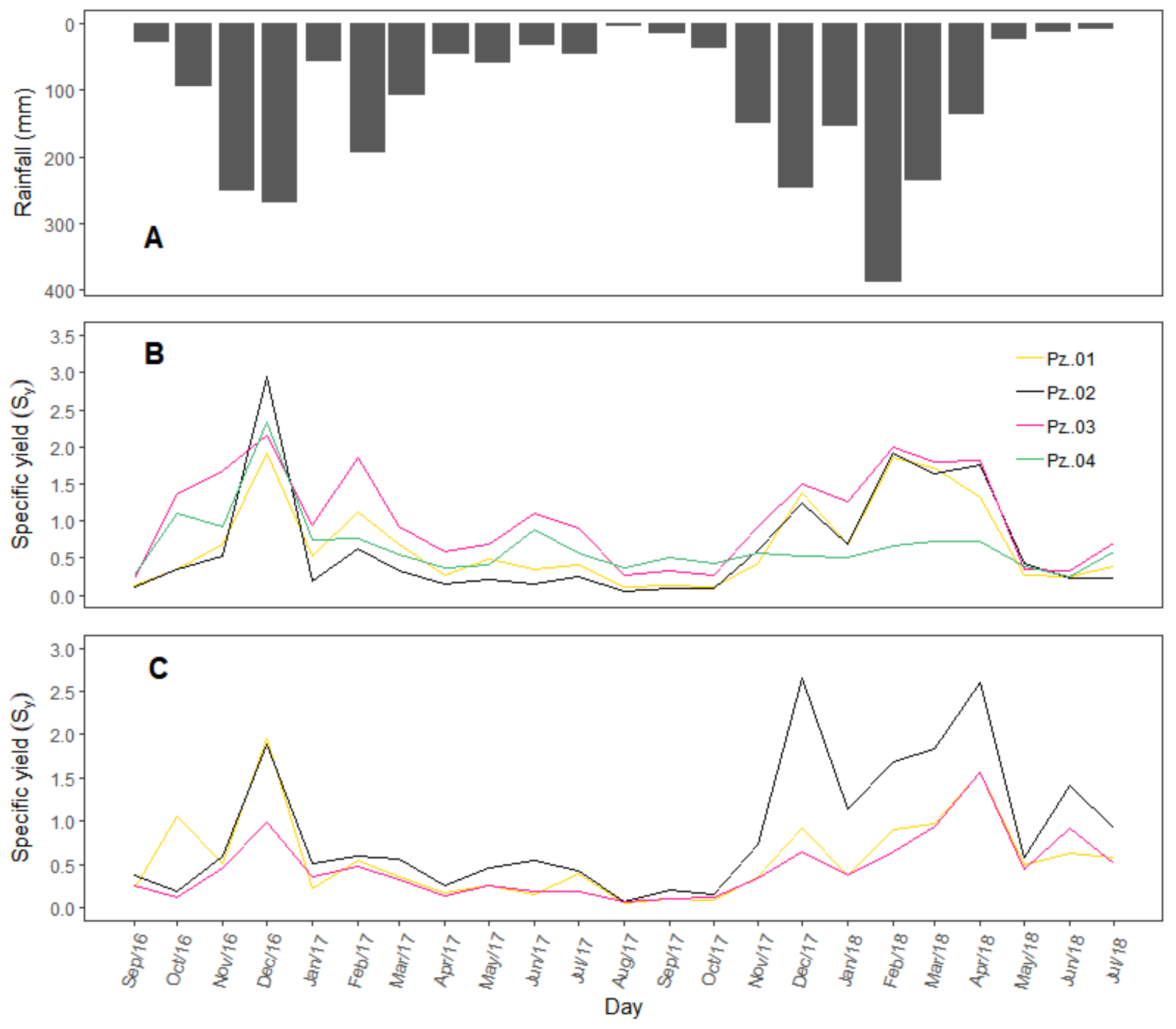

Figure 7

Legend not included with this version

Figure 8

Legend not included with this version 

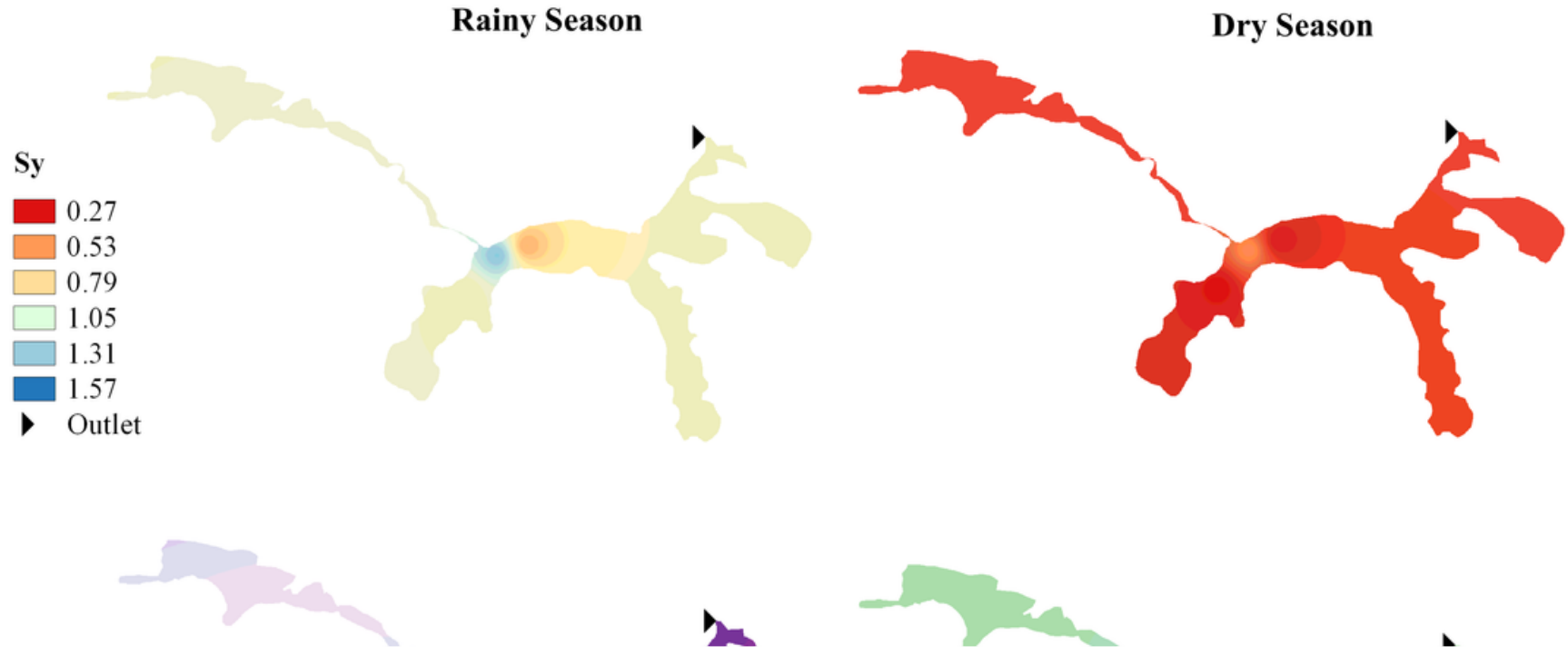

-

\section{Figure 9}

Legend not included with this version 

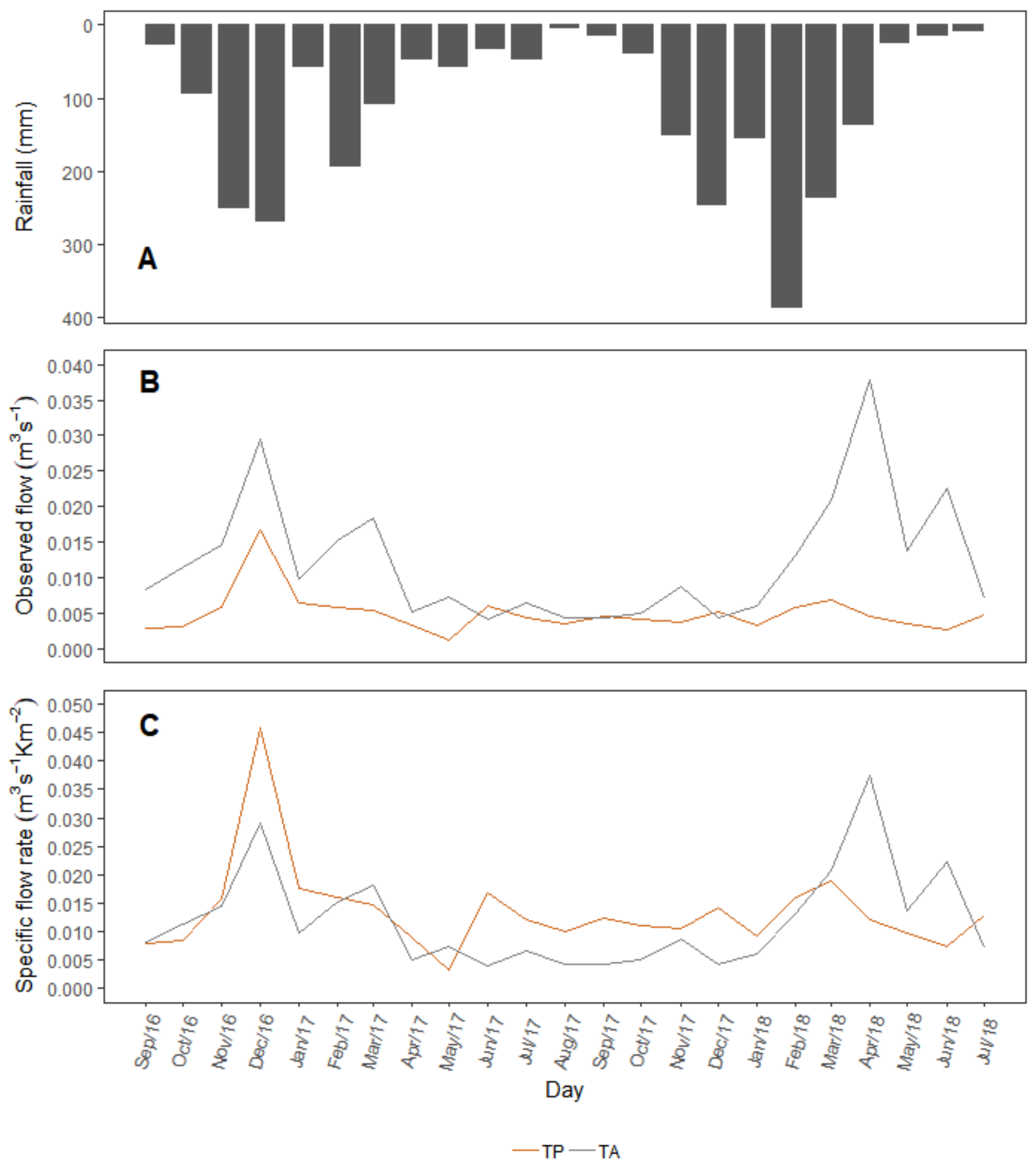

Figure 10

Legend not included with this version 